\title{
Afghanistan Today
}

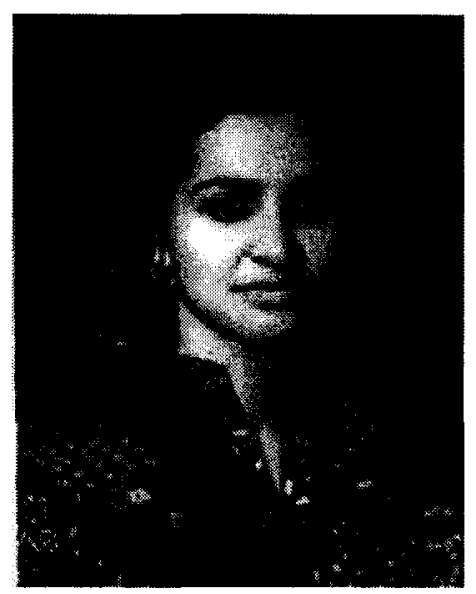

\author{
From the BOARD of EDITORIAL ADVISORS, Ms NASIM \\ ZEHRA takes a long dispassionate look at AFGHANISTAN as it is \\ under the TALIBAAN

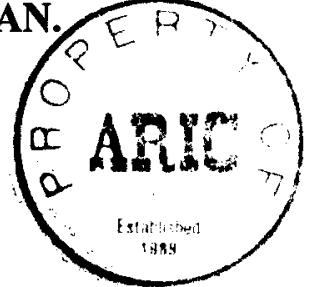

Like most realities the Talibaan phenomenon manifests the complex with the simple and the positive with the negative. Like all other realities, it is one that is also based on paradoxes. Yet hidden behind the veil of censure by numerous governments human rights organizations and sections of the international media, this is mostly an untold reality. Having created, in its earlier days a generally harsh and inhospitable environment for visitors and having adopted a "ban-television" policy, had also amounted to a posture of self-imposed isolation. Matters have improved. Yet naturally negative perceptions are hard to replace. Especially when in the war of waves you hand over a voluntary walkover to your critics.

Today's internal Afghan reality is a cumulative outcome of yesterday's happenings. Undoubtedly the 1979 Soviet invasion of Afghanistan triggered the happenings, but many others contributed to processes that helped to create today's Afghan reality. Most of those responsible for the circumstances that created today's Afghan reality have walked away from it. Others dislike it and seek its demise. Some seek its well-being. Afghanistan's recent history needs no recall. In the eighties prompted by a mix of blatant power play compulsions, inorganic ideological considerations and geo-strategic calculations, the Soviet Union and the United States had dedicated immense attention and resources to various Afghan groups. Pakistan too had placed itself in the triple role of the beneficiary of US military and economic support, the benefactor of the Afghan Mujahideen and the host for millions of Afghan refugees. In the nineties an unravelling began.

Defeated the Soviets exited from Afghanistan and their beneficiary Najibullah too had his last tragic hurrah in 1992. Najib's exit marked another phase of destruction, devastation and social anarchy and betrayal in Afghanistan. The weapon-laden bitter harvest of competitiveness and intense intraMujahideen rivalry wreaked havoc on the Afghan people. If the 1979 Soviet invasion triggered defiance among the Afghans, the post-Najib developments triggered revulsion. The post-Najib phase lasted until 1996 when the Talibaan forces took over Kabul. A ruined Kabul and some 'enriched' Mujahideen commanders now settled abroad, tell the tale of politically and materially ambitious men.
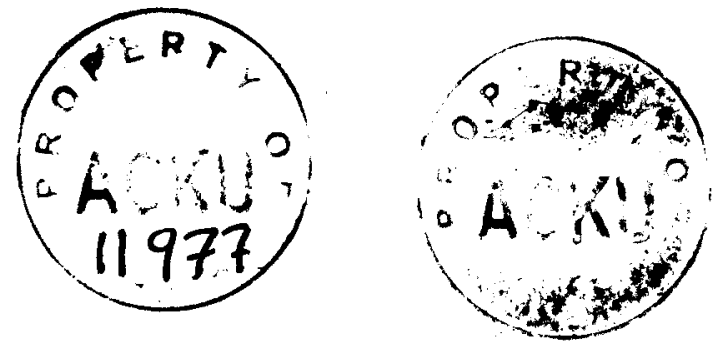
In this current post Soviet and post-Mujahideen there exist only two political forces in Afghanistan, the Talibaan and Ahmad Shah Massoud. While both generally enjoy peoples' they are vastly unequal. The Talibaan control the seat of power Kabul while Ahmad Shah Massoud is restricted to the Panjsheer Valley; the Talibaan control around 85 to $90 \%$ of Afghan territory while Massoud controls around $10 \%$; there have hardly been any dissension in the Talibaan ranks ever since they took off from Kandahar in late 1994 while occasional defections from Massoud's commanders to join the Talibaan have taken place; despite the domination of the Kandharis within the Talibaan leadership in Kabul in the provinces the Talibaan have managed an ethnic collage of collaboration enabling them to extend and retain their influence in even the non-Pushtun provinces while Ahmad Shah Massoud centered ethnic collage called the Northern Alliance could not be sustained. Only Ahmad Shah Massoud through his admirable skills of a guerilla commander, peoples' support and external military and economic support, is able to keep the Talibaan away from the Shumayli zones.

The absurdity of the United Nation's recognition of the Jamiat-i-Islami leader Professor Burhanuddin Rabbani, now found either in Tajikistan, Iran or the restricted zone of his hometown Faizabad, as the Afghan President notwithstanding, it is the Mulla Umar led Talibaan government that controls and administers Afghanistan. It is a government that faces the tough task of administering a state which has rarely, beyond four or five provinces, boasted of a western style state structure. Instead the Afghans have lived with an organic administrative structure, delivering minimally to the public but maintaining effective social peace and stability. Authority and legitimacy of this organic system has been derived from tribal traditions and practices.

While superficial conclusions about the Talibaan blame them for imposing 'alien' ways on the Afghan public, especially religious extremism and ethnic exclusions, it is the Talibaan's ability to understand, accept and assimilate the organic ways of administering Afghanistan that has made their sustained control possible. Talibaan's influence and control on the $90 \%$ of Afghanistan's provinces is directly linked to their ability to keep the population and especially the tribal influential satisfied; mostly in terms of maintaining peace and security and providing livelihood opportunities which would mostly mean agricultural activity but without disturbing the tradition-bound practices.

In this regard especially the Talibaan leadership has demonstrated an ability to correct its own mistakes. For example in February under great public pressure the governor of Paktia Abdullah Aga a Kandhari had to be replaced with Mulla Shafiq another Kandhari. Abdullah Aga who failed to appreciate the local traditions including the power of the jirgas and their Khans had also started distributiing state land in Khost to outsiders. Intelligence reports were despatched by representatives of the Ministry of Interior to Kandhar and Aga was appointed as head of the Afghan Red Crescent Society. Reportedly a local uprising in 1999 in Khost also demanded more state expenditure on development work and less on war.

The significance of social peace and security for the Afghans has emerged against the backdrop of a twenty-year war. For example the traditional respect from women was replaced by whimsical attitude of some Mujahideen fighters towards the Afghan women. According to one source when a widow refused to allow a Mujahid fighter marry her young daughter, he did so forcibly maintaining that "we fought an 11 year jihad for your safety and you won't let me have your daughter". He married her and then left her after a week. Three vears later the mother got permission from a Talibaan leader to 
remarry her daughter.

Another story that many people repeat is about Zardad, a Gulbadeen Hikmatyar commander. Stationed about 40 kilometers east of Kabul at Sarobi, Zardad had set up a check-post to 'tax' all those entering Kabul. Zardad's men searched those entering Kabul and removed any valuables they found claimworthy. In case valuable possessions were not visible Zardad's men would call for a special searcher 'nick-named' dog in pushtu. 'Dog' would then wildly 'paw' the travellers bodies forcing them to beg fellow travellers for money which they would hand over to Zardad's men. Zardad too fled the scene as the Talibaan advanced towards Kabul. Enriched by his check-post 'earnings' Zardad is now reportedly settled abroad.

While the validity of these stories cannot be independently verify, the fact that the Talibaan lashkar were welcomed in many provinces, by either the local people and the commanders points to their estrangement from the Mujahideen leaders. Such was the psychological impact of the Talibaan's easy advance from Kandahar towards Paktia, Gardez, Logar, Sarobi and Kabul that people kept saying these are men fighting for Islam and if you fire at them the bullet comes back to you ! In other areas like Herat and Mazar-i-Sharif the Talibaan gained control through both fighting and through defection of opposition commanders. Talibaan, an army of rag-a-tag even if devoted Talibs, led by men who are in ministerial chairs one day and in battle-front bound hilex trucks the next day, are no great military strategists.

However, having past the goal post of security, relative calm and the country's unity three years ago, the Talibaan are confronted by additional challenges. While trade activity continues through the traditional Pakistan, Iran and Turkmenistan routes, people naturally require the government to deliver on multiple fronts; rehabilitation of the hundreds of thousands of internally displaced refugees, reconstruction of infrastructure destroyed during the war, rehabilitation of the agricultural system, revival of whatever minimal industry, provision of basic amenities like food, water and health services. There also a vocal minority that calls for rehabilitation of education facilities. Those used to studying in educational institutions imparting quality and contemporary education, the imposition of the government dictated curriculum and the discontinuation of higher education would like to see the return of quality education. Although education previously banned for women has opened up for girls up to eight years of age, especially in provinces outside Kabul, the 2,000 women sent packing from the Kabul university would want to return to the university.

There is no less a feeling in some minority circles that the Talibaan need to focus on objectives more consequential than the size of men's beards and the strict enforcement of burqas as opposed to chadors. Although some women working in the health sector have been allowed to return to a segregated work environment many working women still sit at home receiving a percentage of their salaries.

A varied and diverse but largely economically beleaguered and a politically unsettled Afghan population wants the Talibaan government to deliver on many fronts. The peoples' expectation combined with the context within which the Talibaan government is operating, pose a four dimensional challenge to the Afghan government. The combined challenge of an ongoing battle with Ahmad Shah Massoud, of social, economic and political reconstruction of state and society, of dealing with the international demands and pressures and finally enticing the skilled and resourceful expatriate 
Afghans to return to Afghanistan, require a skilled and sophisticated response from the Afghan government. Indeed a tall order. The million dollar question is: Going against all odds can the Talibaan government 'deliver'?

\section{The Talibaan Government}

It is difficult to imagine that they can actually govern a country. It amounts to getting a few hundred people, completely unexposed to either the world of governance television etc, from a remote village of NWFP or Balochistan and asking them to run Pakistan. Perhaps in Pakistan there would be a bureaucratic system neither war-ravaged and also vastly more efficient than the one supporting the Talibaan in Afghanistan. Talibaan are battle-hardened men mostly trained in madrassas. They have no experience in managing institutions, in engaging with hard core economic, social development, foreign policy issues. Majority of them have studied in the Pakistani madrassas based in Karachi, Akora Khattak, Faisalabad, Multan and various parts of NWFP. They all sport long beards and wear shalwarkameez. None speak English. They have virtually no experience of interacting with women, other than their family women. In their madrassas they have been imparted religious education according to which the dictates of Islamic morality and social peace require that Shariah is enforced and Sunnah is followed. Photography, they are taught is unIslamic and photographs 'haraam.' The camera-based world of communication the television has been unknown to them. In fact television, they have been taught is unIslamic as is music and film. Men must grow beards, women must be clad in burqas, gender-segregation in all institutions is a must. They know it is the state's responsibility to enforce Hadood punishments for theft, adultery and killing. Riba too must be banned. Above all they believe that the state must provide for the poor and the destitute in society. All this broadly constitutes the worldview of the Talibaan.

Talibaan are the rural men of Afghanistan. Their madrassa acquired worldview mostly finds a resonance in their own age-old traditions. The moral decline in Afghanistan that accompanied the Mujahideen resistance against the Soviets made their teachings more relevant for them. Also for the suffering in society. In recent years the young Afghan talibs, trained also in Pakistani madrassas, eagerly joined the ranks of the Talibaan fighting against various Mujahideen groups. Often led by former Mujahideen commanders, and motivated by the madrassa teachings to fight the 'immorality' of the other Mujahideen groups and to establish the madrassa taught system of morality, the young talibs are volunteers in Mulla Umar's rag-a-tag army.

Now in power for five years the Talibaan leadership is confronted with a dual challenge; of keeping the talibs flowing to the front and at the same time administering Afghanistan. Mulla Umar, the Ameer-ul-Mumineen of the Talibaan, directs an elaborate Afghan government machinery. Sitting in Kandahar he remote controls $90 \%$ of Afghanistan through his Talibaan nominees. They occupy positions in various bodies; a six member Kandahar-based shura, a six member Kabul-based shura, a twenty-three member Council of Ministers and around forty deputy ministers, twenty-seven governors and six corps commanders. Abdul Wakil Muttawakil the foreign Minister and Mulla Jaleel Akhund the deputy Foreign minister are supposed to be his most trusted men.

The Holy Quran is the Constitution of Afghanistan. Assisted by his Kandahar and Kabul -based shuras Mulla Umar takes all major decisions related to policy, administration and war matters. His farmans are the equivalent of presidential ordinances and are promptly implemented. All postings and transfers 
from ministers to Director-General level are ordered by Mulla Umar. Often ministers whose performance is considered unsatisfactory, based on Mulla Umar's own information networks, they are demoted to deputy minister or director-general level. His orders are promptly implemented. In military matters too, based on advise from his commanders, Mulla Umar takes the final decision on military moves. All advances and retreats are based on his orders relayed to the front through his wireless contacts.

Given the system that work arounds Mulla Umar essentially the mode and structures of government operations generally remain unchanged. If earlier it were kings and Soviet-Union backed Presidents now its Mulla Umar assisted by his shuras retaining the authoritarian character of the government. Often orders of ministries can be overlooked by local commanders, while dealing with aid workers. Only Mulla Umar's word goes unchallenged.

He draws the broad contours of strategy and policies. His nominees, assisted by the pre-Talibaan bureaucracy, are responsible for implementation and monitoring. All of the key men who administer the ninety percent of Talibaan-controlled Afghanistan are men trained in the madrassas of Pakistan. The overwhelming majority of those who are ministers and deputy ministers are inexperienced men and with minimal urban exposure.

Despite all the destruction and a partial, though seasonal, state of war, the Afghan state is a functioning state. There is a structure, there are ministries. Some work better than the other. Three categories of staff run the government; at the top are the Talibaan leaders, the middle are mostly the left over from the communist era and the third lowest rung support staff. For example in Kabul the traffic system is highly organised, controlled by pant-shirt clad traffic police. The state collects duties on imported items at the centre and in the provinces. In the Ministry of Interior and in the Traffic Police headquarters passports and driving licences are issued. Currently the Ministry of Foreign Affairs is making arrangements for the departure of 9,000 Afghan people for Haj.

The Ministry of Interior manages the police, the intelligence and the highly effective intelligence network. Interestingly to enable state functionaries and the Talibaan leadership to move in Kabul around during the curfew hours a new password is issued every night by the Ministry of Interior. And there has been no security lapses in the issuance or the use of the password. There are also Talibaanmanned functioning check posts and toll-tax collectors stationed along the road from Torkham to Kabul and onwards to Logar. Efforts, although slow and resource-starved, are underway to inject academic life into the war-destroyed Kabul university. Although not as the government of Afghanistan, the Talibaan still sign and honour agreements with the UN agencies for humanitarian work.

Reportedly the usual practice is of weekly meetings of the Ministers Council and fortnightly internal ministry meetings; communication occurs through memos and verbally among officials. Routine performance checks are conducted of functioning service outlets like health centres, primary schools etc by ministers and director-generals. Discuss issues and take decisions and then decisions relays through tehreerat (pass orders).

The state continues to be the largest employer. According to figures provided by the ministries, in the Ministry of Works there are around 12,000 people employed. in the Ministry of Communication 
around 4,000, in the Ministry of Education around 32,000. With its very limited resources the Afghan government pays very low salaries. Average salaries ranges from one hundred to three thousand Pakistani rupees. The result is obviously poverty-struck, de-motivated, moon-lighting and, therefore, exhausted government employees. Discussing their salaries most Afghans question "Can anyone survive on this, how will we feed our children, our families?" Can anyone survive on this much. All government departments are headed and controlled by the Talibaan who are obviously nonprofessionals. Whether it is the educational ministry, the Kabul Times newspapers, the Kabul University or the Kabul Police Department, professionals work under the Talibaan. The working conditions including extremely low salaries leave the professionals fairly disheartened. According to an agency representative regularly interacting with the government, "The administration is functioning only $5 \%$ and many from the administration are involved in fighting." Ministers and deputy ministers also regularly fight in the jihad. These days most have gone to the front for jihad.

Visits to various ministries and departments, discussions with around a dozen ministers, with numerous non-Talibaan government officials and with representatives of aid agencies who regularly interact with the Afghan government, provided an insight to the working of the Talibaan government. The Talibaan government is gradually realizing the demands of administration and of public service.

In government they are assimilating new ways. Pragmatism prompted change is abundantly visible: some of the Talibaan ministers now appear on television, they have withdrawn instructions to blackout all photographs appearing in any foreign newspapers entering Afghanistan. The Talibaan now regularly invite representatives of international agencies to business luncheon meetings at the Kabul Inter Continental. First they would maintain that foreign agencies and NGOs were not required. Now they are welcoming them.

Some of the ministers even receive women delegates from foreign agencies and the more reluctant like the Deputy President of Council of Ministers Mulla Hasan are convinced by Ministers of Repatriation and Planning to meet with the woman Director of Care. Refusal to meet will close down the muchneeded Care programme. He agrees warning there will be no other exception to his rule of no meeting women. Many within the Talibaan leadership know this must gradually change. Perhaps the celebration of the March 8 International Women's Day in Kabul by the Talibaan illustrates their resolve to adjust to some of the acceptable ways of international community they are keen to engage. Significantly the order that women will not leave their homes alone is no longer operative. Instead talib guards sit armed in small vans monitoring male movements in women-packed bazaars around Kabul's Bagh-i-Omoomi. The men from the Ministry of Promotion of Vice and Virtue too have a low profile presence compared to the past when they would regularly check and beat men with short beards and women without the appropriate burqa and dark coloured socks.

Despite the fact that only three countries have recognized the Talibaan government, its exposure to the outside world is gradually increasing. Ministers have regularly been invited abroad for seminars and conferences. The Chief Justice went to Budapest for a 19-day conference on Organised Crime. Officials of the Ministry of Water and Power went to the US for meetings with UNOCAL consortium, the deputy minister for public health Mulla Abbas Stanakzai is currently attending conference on public health in Kathmandu, Mulla Rabbani the President of the Council of Ministers has visited the Gulf States, the Minister and Deputy Foreign Affairs Ministers have visited numerous European and 
regional countries including China.

The Talibaan's onward journey as the government of Afghanistan is a precarious one. Faced with an unfinished battle with Ahmad Shah Massoud, the political skirmishes and minor uprisings, acts of attempted sabotage in Kabul and an unabating propaganda war the Talibaan find it difficult to open their top ranks for skilled expatriate Afghans, that it needs. Additionally Afghans, who seek good career prospects and are not driven by sheer patriotism, will not return to the very difficult socioeconomic environment. Opening up in the military ranks has, however, occurred. For example a key person General Saafi, a former brigadier-general in Zahir Shah's army, a former Mujahid commander and a member Peer Sayid Gaillani's NIFA, has joined the talib. He is now a Talibaan representative in Europe.

The Talibaan government, with all the difficulties it faces, shows no sign of surrendering to pessimism or frustration. It remains determined to undertake, with dignity and devotion, the colossal tasks of reconstruction and rehabilitation. In their meetings with the UN agencies the Talibaan firmly convey their own agenda to them. Reportedly the Amr Bin Maroof minister told special a UN Rapporteur that, "we had our own priority our country was to be divided into various parts, our first priority was to ensure our country's unity, now we will work in other areas."

Given the sociological background of the Talibaan, their adjustment to the world of governance can be categorized as radical. Despite their determination, easing of external pressure and the streamlining as well as relaxing their own system of government, is a pre-requisite for the success of the Talibaan government.

\section{The Ossama Issue}

The Talibaan government has earned its staying power from the specific Afghan context. Five specific factors are responsible for giving a rudimentary character to this context: the continuing hold of tradition, the exit of the majority of western educated elite, a largely destroyed productive physical infrastructure, an invasion and war-triggered largely reactive socio-political mindset of the overwhelming majority of the Afghans living within Afghanistan and an economic scene that has virtually no institutionalized link with international capital, international structures and internationallycertified norms of acceptable state behaviour. The absence of an aid-dependant mindset prevents the Afghans from linking key decisions in terms of international earnings and goodwill they could generate for a cash-starved poverty-struck suffering people. Hence it is largely an inward looking contex; although seeking humanitarian aid which many believe is a war-torn Afghanistan's right given the United Nations' mandate to support a beleaguered international human rights norms.

The men who now control about $90 \%$ of Afghanistan apparently remain content with their mode of interaction and to a great extent with the fundamentals of their own traditional and madrassa-tutored worldview. Nevertheless by changing their ways in certain areas they have demonstrated that they are not violently attached to their worldview. However, only those adjustments are made which they believe will not violate the fundamentals of their traditions interwoven with their own interpretation of Islam. While change in their ways and in their stated positions is necessity-provoked, it also must be logic-backed. For example the very gradual easing of controls on women, moving from the position of banning television to "starting television in Afghanistan when enough good quality programmes can 
be produced", granting diplomatic immunity to UN staff, permission to burqa clad women to drive cars, acceding to the UN demand of placing human rights monitors in Afghanistan, replacing their antagonistic rhetoric against those countries hostile towards it with talk of peace and dialogue etc.

Naturally in government the Talibaan's views and practices are being moderated. Through external influences and an internally secure situation more opening up too is inevitable; provided no major military or political upheaval applies another reverse gear on the Afghan society. The pace of change will not even be enough to satisfy even Afghanistan's neighbours who view banning of women from the workplace and from educational institutions as completely unIslamic. For those, including expatriate Afghans, critiquing the Talibaan from western capitals may view them as cave-men.

Contesting these assertions Afghanistan's deputy foreign minister and an influential member of the Kabul shura Mulla Jaleel argues that, "I think the world's faulty understanding of Afghanistan and its inability to fully understand our problems is perhaps the biggest factor that is preventing the government of Afghanistan from solving the problem of the people. Does the world not know that the government of Afghanistan controls $95 \%$ of the territory and the capital Kabul is also with us. How then can 5\% people, the opposition, be confronting us." The Talibaan are actively seeking constructive engagement with the outside world. "We are going and telling them our reality now and we hope they will better understand us" hopes an official of the Afghan Foreign Office.

The Talibaan government maintains that their willingness to engage with its critics has extended to even the most complex question. Naturally the Ossama question.

Over half a dozen direct Talibaan-American talks have taken place on Pakistani soil to discuss the Ossama issue. The Talibaan have asked the Americans for evidence against Ossama and have undertaken to hold his trial in their own Shariah court. The American-Talibaan deadlock continues over the Ossama issue. No breakthrough is imminent because the Talibaan government will never accede to the one-point American demand that Ossama be surrendered to Washington. In fact no Afghan government would ever be able to accede to it since it violates the inviolable Afghan traditions of hospitality and of loyalty.

The Afghans realize that there is a price tag attached to their position on Ossama. According to a major Talibaan commander and a former captain in Daud's army, "the Ossama problem not helping us, he has caused American sanctions." But the commander defends his government's position. "We told the US that Ossama will not create any problems against the Americans but the US has not understood what is to their own advantage," laments Commander Deedar. He warns that "If Ossama goes to any other country he can do whatever he wants but here we have stopped all his activities and he can carry no operations.

"Mulla Jaleel, the deputy foreign minister was also questioned about the Ossama issue. "Ossama is our guest here. Ossama's whereabouts were known to Saudi Arabia and America all along. Then we told the Americans that he wants to leave Afghanistan but they are demanding that we hand him over to the Americans," said Mulla Jaleel explaining the background. "That he categorically said "is not acceptable to us because Americans who have unilaterally declared him a criminal cannot give him a just trial". Explaining the Talibaan position he said, "We have offered to hold of trial of Ossama under our Shariah courts if the Americans give us the solid evidence. However, handing over Ossama to the 
Americans goes against our tradition, religion and spirit of hospitality.”

Complaining against the west the deputy minister queried, "I ask the west that what justice is it that they have kept a shaytan (Satan) in their own country, made him their special guest and turned him into a hero when his crime of blasphemy has been and continues to be decried by the millions in the Muslim world." Bending forward, as if to stress his point he had said, "You know I am talking about Salman Rushdi."

Taking pride in his government's ability to handle Ossama and make good on their commitment Mulla Jaleel added, "As for Ossama we made a commitment to the world that from our territory he will never undertake any terrorist act. Today he is under our complete control. He has no wireless system, he has no telephone and has, therefore, no communication with the outside world. He is a helpless, harmless man. The US should be thankful to us. They had themselves encouraged and practically helped him to engage in jihad.

The Minister for Repatriation, Martyrs and Disabled Mawlawi Abdul Raqeeb further reinforced the point about tradition. "It is not a personal matter, it is a matter of four principles, religion, faith, jihad and hospitality. No one dare violate any of these," he said ruling out any change on the Ossama issue.

The Afghans are a proud and determined people, aided also by a cunning that they have acquired by being on the cross-roads of history. Interestingly on the Ossama front the Talibaan are also replaying a chapter of their own history with striking similarity. During World War II in October 1941 the British and Russians demanded that the Afghans expel all non-diplomatic Axis personnel. They claimed some were responsible for Allied casualties along the frontier. The then Afghan Prime Minister and his team did not doubt that in case he refused this demand, an Allied force would invade Afghanistan. Iranian refusal of a similar Allied demand had provoked a joint British-Russian invasion in August 1941. Despite this Iranian example the Afghans did not consider immediately and unconditionally obeying to the Allied request. A former US government employee and Historian Louis Dupree in his authoritative book Afghanistan (1980) writes "Despite this the Afghan Prime Minister considered the Allied ultimatum as an insult to traditional Afghan hospitality and neutrality, an affront to the Muslim custom of sanctuary and a slap at the growing national integrity of a small nation." Instead the Afghan, according to Dupree, ordered all non-diplomatic citizens of the "belligerent" nations Japan, Germany and Italians, to leave. The British agreed to permit free passage to the deported personnel through India.

Even now the Afghans had offered safe passage to Ossama so he could leave Afghanistan. Instead Americans demand that he be handed over to them. There was more humility in the mid-twentieth century. A visible balance of power scenario, even if tilted during the World Wars, helped to resolve complex matter. Through mutual accommodation. Now some nations may often behave as if these are times of the conquerors and of the vanquished; throwing reconciliation regrettably to the winds.

\section{The Changing Shades}

There are many sides to them. The severe and the flexible. The angry and the understanding. Not least the simplistic and the sophisticated. Whatever their education and experience, during discussions the Talibaan ministers reveal sound understanding of their problems. Their approach is context-bound 
and, therefore, logical. Leaving aside the issues of social freedoms they fully appreciate the political, economic, humanitarian and foreign policy problems. They have moved sensibly in these areas. The Talibaan journey from their birth in 1994 to their five years in government, is a fascinating one in terms of their learning process.

The learning within the Talibaan has also been at varying degrees. For example many of them are not able to contextualize power using conventional standards. They comprehend power with reference to their own level of courage and determination to engage with an adversary. Their reading of power, politics and people is mostly straight forward. Often, in-keeping with their own exposure generally one dimensional. For example in August 1998 when the danger of an Iranian military offensive died down, a Talibaan commander Amin Qudrat said "thank God He saved the Iranians from our wrath!" This sentiment completely ignored the prevailing ground realities. There had been heavy concentration of Iranian forces along the Iran-Afghan border from Nimroz to the Herat province. In response the Talibaan were forced to withdraw around 30,000 talibs positioned on the frontline with Ahmad Shah Massoud to place them along the Iranian border.

Similarly as the story goes when a Pakistani official said to a talib leader that the world has congratulated us about our nuclear tests but we have not heard from you , the talib leader told him "we don't believe in empty congratulations, you tell us when you are going to liberate Kashmir and you will find us marching ahead of your forces." In Dehli, Washington or elsewhere such words may become basis for academic and policy conclusions that the Talibaan are fighting the Kashmir jihad or even more, a global anti-western jihad. But contextualizing such statements within the Talibaan world is needed. The Talibaan world is normally informed by sentimentality, loyalty, sense of injustice and even anger. Whatever their statements the Talibaan world is largely defined by their own internal crisis. In power Talibaan's obsession is nationalism and reconstruction, not the CIA-ISI tutored global jihad. That demonizing and political, diplomatic and economic aggression by the world may turn them in a different direction, is however possible.

Similarly at the height of the Pakistan-US problem over the F-16 a very senior talib leader said to a smiling Pakistan ambassador that "look America had taken so much money from you and not giving you your planes and you Pakistanis are extremely patient. If they had done this with us we would have attacked them by now." The talib had no comprehension of what such a move entailed, of the equation between the two countries in terms of military power and the distance between his country and the United States.

The sheer lack of exposure to worldly matters of the Talibaan leadership was obvious in a decision taken by the governor of Jalalabad. When he took over in Jalalabad, he heard about the Engineering university in Jalalabad. On being asked "what happens at the university "he was told "it is engineer Hikmatyar's place which produces his followers." The governor ordered the shutdown of the university. He ordered its reopening when he later knew the facts. Later in 1998 when the US fired missiles at Khost and a Pakistani diplomat in Jalalabad went to inform Maulvi Abdul Qabeer the acting President, that the missiles had landed near Khost the bewildered acting President asked "what does America want from me. Deciding to retire for the night he added, "anyway I will think about it in the morning I must sleep now."

These simplistic ways of the Talibaan had extended to many areas. On the streets of Kabul and 
Jalalabad the talibs would frown at those who sought diplomatic immunity. Of the few diplomats that remained in Kabul almost all had memorable experiences. Diplomats of a country found themselves at a police station for not sporting a beard. UN cars would regularly be checked. Talibs would object to women occupying the front seat. Newspapers with any photographs would be confiscated, cassettes in the cassette recorder removed, the tape pulled out and criss-crossed on the nearest tree trunk!

In Afghanistan entertainment in the form of music, television, and movie halls has been declared illegal. It is in Kabul where this ruling is most strictly enforced. In Kabul obviously capital compulsion at work; to demonstrate government control at the optimal in the seat of power. This firmness is also required to keep the battle ranks in tact. A Talibaan-defined religious fervour is seen as a pre-requisite to keep the zest for martyrdom among the young talibs who battle against Ahmad Shah Massoud.

Nevertheless behind the apparently harsh morality is the naturally and traditionally fun-loving individual. The guards stationed outside an embassy in Kabul regularly play the flute. In a small suitcase parked in the guardroom are stored Indian song cassettes, videos of a famous Afghan singer Naghma. Interestingly a search by some individuals for a video of the movie Titanic ended when a Talibaan guard produced the video! At another location after dinner time there were a couple of Talibaan guards entertaining themselves by performing the Khattak dance! Upon being discovered they ran behind a nearby bush. During our journey from Kabul to Logar a Talibaan official urged us to play the cassette recorder lest we concluded there was no music in Afghanistan. All this is more than window dressing. It is attraction for what is pleasing and enjoyable.

Shades of leniency extend in the public arena. Noticing my movie camera people on the streets of Kabul mostly smiled. I tried to be discreet, but many wanted to be photographed. Most Ministers smiled when requested to be photographed. Photography goes against the orders of the ministry of Vice and Virtue. Yet the ministers representative at the Kabul police department allowed photographing of police officials. Similarly in a small town in the Logar district, south of Kabul we first went and had tea inside a small restaurant. Later I walked along with a young girl to an automobile workshop. People in the bazaar barely noticed us.

Political struggle and human survival, often in touching tunes, continue. The struggle for Afghanistan remains a three party struggle: the Talibaan occupied centre-stage, Massoud at the margins and the expatriate Afghans at the very distant margins. The Afghans meanwhile live life in its uncontrived forms. Driving from Jalalabad towards Kabul scenes of normal life flash by. Klashnikov carrying, lawenforcing Talibaan rest by the wheat and poppy field. Without fail in virtually every cultivated field men, women, little boys and girls are working together. We are informed that for some individuals the inevitable pursuit of wealth too is underway. Landed men busy reclaiming land that was taken away during President Tarraki's time. Tarraki had allowed only 12 acres and redistributed the rest. Now through the Qazi courts some people have successfully reclaimed their land.

Nearby life mingles with death. Three little girls play, in the corner of a graveyard, play with tiny rocks. At some distance a little girl and boy playfully shower affection on their baby sister. Illustrating the Afghan suffering little boys and girls in batches and alone, occasionally fill potholes on the road with mud. Waving frantically they stand on the road asking for money. Others were also playing football, wheel-rolling, car watching and pebble throwing. Closer to Jalalabad, walking through the fields, little girls in uniform head for school. Squatted on the ground eight men attend an 'oolaswali', a 
town committee meeting. Water pipes are under repair by a group of men huddled together, as young girls work in the fields. Watching all this are Speenghar (white) and toorghar (black) ranges of Nangharhar area. Effortlessly, they boast their snow-clad peaks.

Nested along the main road is also the unassuming Jalalabad airport. Surprisingly it has remained an 'active' airport. Until the November UN sanctions twice a week flights would go from Jalalabad to Amritsar, to Dubai and to Sharjah. Now only passengers for domestic flights wait outside in the open air waiting room. Outside the airport gate men, women and children with bundled belongings sit on the roadside waiting to be called in to board the flight.

As we leave Jalalabad behind the Tangi area of the Kabul province appears. It is marked by imposing barren mountains harbouring smooth contours. Like the gun and the rhubarb combine in the Afghan milieu. Between the mountains flows the gorgeous unspoilt river Kabul. During the Soviet occupation peaks of these imposing mountain peaks were occupied by Hikmatyar's hardy men. Dinky-statured remnants of Hikmatyar's weaponry is still visible on the mountain peaks. From the mountain peaks the resistance men had attacked the Soviet convoys moving under cover of MiG helicopters. In their pristine form these mountains mirror the unyielding side of nature.

Clearly the Soviets triggered a tectonic upheaval inside Afghanistan, the Americans don't like what they helped produced. The Afghans inside Afghanistan meanwhile continue their attempt at reconstruction and rehabilitation. They know consolidating their hold depends on meeting some basic needs of the people. As they confront these monumental tasks of reconstruction, they often question the complete absence of support from the international community. From Muslim and non-Muslim states alike. After all, they wonder, only yesterday they were a pampered people. The international community had supported them endlessly as they encouraged them to wage a war to "roll-back the evil empire." Today they feel ostracized, and wronged. Their own explanation for them is the most plausible; "because we are an Islamic state, we are an independent Muslim state the western countries want us to fail" explains one Kabul-based minister. A more understanding Mulla Jaleel, a key aide to Mulla Umar says maybe "they don't know the truth about us, about our difficulties or maybe they are prejudiced against us." The Minister for Public Works, supporting a wooden leg wonders, "maybe because now Kufaar have the most power, only those who accept Kufaar rule then they will have no problem" He hopes for a change of heart in the 'kufris.'

However, Afghanistan is a country which functions at multiple yet unequal levels of progress and tradition. It will not react positively to a one-solution modernisation phenomena. In January 1980 none other than the members of the Institute of Economy of the World Socialist System at the Academy of Sciences of the USSR highlighted this reality. They delivered a letter to the Central Committee opposing Soviet military intervention in Afghanistan. The letter argued that Afghanistan had not reached the level of development where socialism was possible. In fact according to authors of the letter "conditions such as illiteracy and strong Islamic influence do not favour socialist development."

There is an inward-looking Talibaan leadership at work. Remaining attentive to outside criticism but defining its own priorities. Mulla Jaleel stresses the point that "We have never said that we are against women's education. We believe that whatever in Islam is farz (obligatory) for men is also farz for women". However, he qualifies his position and states that "Education and television etc. are important but please understand that the demands for freedom made by the outsiders for the Afghan 
people do not reflect the ground realities of Afghanistan. Education is not an urgently felt need of the 95\% people of Afghanistan. Their priorities are employment which will come through reconstruction, revival of the agriculture and through establishment of industry. This will only happen in an environment of peace, security and stability inside Afghanistan. The rest will follow..." Maybe external support will enable the Talibaan to see the wisdom on moving on all fronts simultaneously. Inside Afghanistan the learning is very slow - the continuing war and the worldview of the Talibaan will militate against a speedier change the Talibaan are most likely a transient phenomenon; at least in their present form and texture they will be irrelevant to a future rehabilitated Afghanistan.
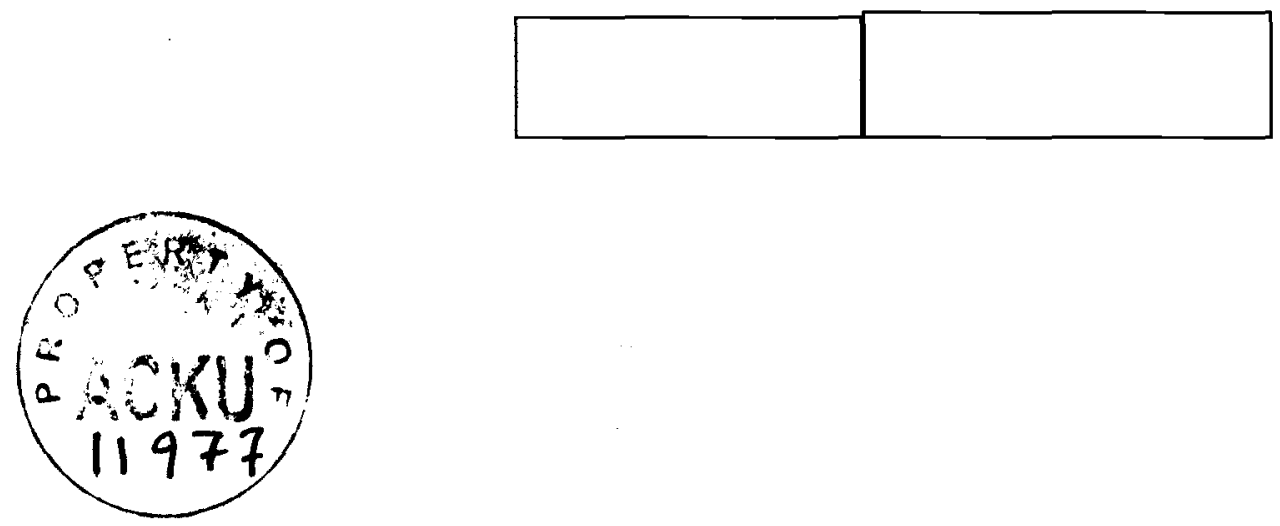